\title{
TRAUMA SYMPTOMS AND PERSONALITY TRAITS IN ADOLESCENTS WITH EXPERIENCE OF CHILD MALTREATMENT
}

\section{Ana-Marija Vejnović ${ }^{1,2}$ Svetlana Ivanović Kovačevićc ${ }^{1,2}$ Valentina Šobot ${ }^{1,2}$}

1 Clinical Center of Vojvodina, Clinic of Psychiatry, Novi Sad, Serbia

2 University of Novi Sad, Faculty of Medicine, Department of Psychiatry and Medical Psychology,

Novi Sad, Serbia

UDK: 616.89-008.44-052.3-02 doi: $10.5937 /$ engramil $1902034 \mathrm{~V}$

\section{Summary}

Introduction. Child abuse and neglect is a general problem all around the world. It may result in the physical, psychological and social dysfunction of the child and it may cause serious consequences in the adult life. The aim of this study was to examine trauma symptoms and personality traits in adolescents with experiences of child maltreatment.

Material and Methods. 60 participants of both genders aged from 12 to 18 years were divided into two groups (group of abused children and adolescents - group A and control group - group C). Five questionnaires were used: General Questionnaire, Wechsler Abbreviated Scale of Intelligence, Trauma Symptom Checklist for Children-Alternative (TSCC-A), Childhood Trauma Questionnaire (CTQ) and Adolescent 
Temperament and Character Inventory (ATCI-46). Statistical methods included Student's T-test.

Results. In a group of abused children, $46.67 \%$ children were neglected, $10 \%$ physically abused, $3.33 \%$ were emotionally abused, while $40 \%$ suffered several types of abuse. In group C, children are significantly more self-directed $(\mathrm{p}<0.001)$ and cooperative $(\mathrm{p}<0.05)$ in character, and more persistent $(\mathrm{p}<0.001)$ than children in group A. Anxiety, depression, anger and posttraumatic stress are more present in group A.

Conclusion. Multiple and long-term emotional difficulties in adolescents with experience of childhood abuse point to the specific needs of abused adolescents for psychological and psychiatric support and treatment, in order to prevent and mitigate the consequences later in adulthood.

\section{Key words:}

abuse, neglect, character, temperament, consequences

\section{INTRODUCTION}

Abuse and neglect of children has been defined by a general definition provided by the World Health Organization, which states: „Abuse and neglect of children consist of all sorts of physical or/and emotional abuse, sexual abuse, neglect or a careless act, as well as commercial or other kinds of exploitation, which bring to a direct or a potential threat to the child's health, his survival, development and dignity, in the scope of the relationship which involves responsibility, trust and power." ${ }^{[1]}$.

The basic forms of child abuse are physical abuse, physical neglect, emotional abuse, emotional neglect and sexual abuse. In some classifications, exploitation is singled out as a special form of child abuse, and in recent times peer violence and digital violence. A failure to undertake something (neglect) as well as inadequate treatment as an active act (abuse) can be united under the term - child abuse. Most of the situations described occur within the family, and fewer in schools, groups and organizations to which the child belongs ${ }^{[1,2,3]}$.

Genetic factors and environmental influences are important for the development of the brain. The child is born with genetic predisposition, and depending on whether it was exposed to positive or negative experiences in childhood, it can result in stable or fragile structure of the brain, good or bad basis for learning, so- 
cially and emotionally maturation ${ }^{[1,4,5]}$. On the other hand, it has been proven that at least negative stimulation gives better results in the development of the brain than the complete absence of interaction with others - neglect ${ }^{[6]}$.

The first doctor who has studied and described forms of child abuse was the French pathologist Auguste Ambroise Tardieu in the 19th century ${ }^{[1]}$. The Convention on the Rights of the Child is the first international treaty that acknowledges the problems of abused children in the family ${ }^{[4,7]}$.

Exposure to childhood abuse is a powerful predictor of an increased risk of developing psychopathological consequences later in life. However, psychopathology will not be shown in every exposed individual despite the traumatic experience, so genetic predisposition is considered to be of great significance in the manifestation of mental disorders. Genetic and epigenetic research in this field is increasing ${ }^{[8,9,10]}$. The importance of other protective factors, such as personality traits and the support of significant persons, is also emphasized. All consequences of child abuse and child neglect can be divided into wounds (death, permanent physical disability, somatic disorders, emotional disturbances, cognitive problems) and later consequences (depression, personality disorders, transgenerational transmission of abuse, psychoactive substance abuse, anxiety disorders, limbic irrita- bility, self harm behavior and suicide attempts $^{[1,11,12]}$. Directly or indirectly, the long-term effects will influence the personality traits of abused children through behaving, thinking and feeling $^{[13]}$.

The child's personality structuring will bear the effects of the abuse and will be marked by a reserved attitude against social networking, by the feeling of stigmatization and negative self-image. The untreated and undiscovered abuse produces serious changes in the structure of a child's personality, major effects in time that can be encountered in the adult's behavior with difficulties of social adjusting and integration ${ }^{[14]}$.

One of the most famous personality theories in recent years is Cloninger's psychobiological model of personality development and structure, which has been extended to childhood and adolescence. According to Cloninger, personality is a complex adaptive system made up of different, but interactive domains of temperament and character ${ }^{[15]}$ and it is the result of the interaction of genetic and environmental factors ${ }^{[16]}$. The Cloninger model is called the Seven-Factor, because it includes four dimensions of temperament (search for novelty, avoidance of danger, dependence on reward and persistence) and three dimensions of character (self-directedness, cooperativeness and self-transcendence). Four dimensions of temperament are universal, predominantly genetically 
based, manifest in early childhood and are relatively stable throughout life, while character dimensions occur later in life and are influenced by socio-cultural factors and maturation. As a result, temperament is more stable in relation to character, so it is expected that traumatic childhood events, such as abuse, will have a greater impact on character dimensions than temperament ${ }^{[17]}$.

Different studies demonstrated that experience of abusive treatment leave an impact on victims personality development, specifically on their emotional adjustment, which may further influence their future wellbeing ${ }^{[18]}$. History of trauma experience is related with higher probability of negative personality traits, like lower self-directedness and cooperativeness and higher novelty seeking, harm avoidance and self-transcendence in adult persons, although causal relationship is not clear ${ }^{[19]}$. Combinations of risk factors from the three domains of temperament, childhood abuse and childhood and adolescent psychopathology make major contributions to the later development of personality disorders ${ }^{[20]}$.

Although in our country year after year there has been an increasing number of reports of child abuse, which is attributed to the increased awareness of the existence of this problem, there is no accurate data on the number of abused and neglected children during the year, due to the fact that a comprehensive system of recording and moni- toring this phenomena has still not been established $^{[1,2]}$. For this reason, it is believed that the research aimed at finding the connection between the experience of abuse with the risk factors and certain forms of dysfunctionality in children and adolescents is of great importance. Findings in these fields would facilitate the planning of means of prevention of violence towards children and adolescents.

The aim of the research was to examine trauma symptoms and specific personality traits in adolescents with experience of childhood abuse.

\section{MATERIALS AND METHODS}

The cross-sectional study covered 60 subjects of both sexes aged 12 to 18 years. The sample was divided into two groups of 30 participants, equally divided according to their age and gender structure: group of participants with experience of abuse (group A), residing in Children's Village "Dr. Milorad Pavlovic" in Sremska Kamenica, and a control group of participants without experience of abuse (group C), with a temporary stay during High School in the Secondary School Students' Dormitory "Brankovo kolo" in Novi Sad during High Scool attendance. The study was conducted in October 2014 in the Children's Village "Dr Milorad Pavlovic" in Sremska Kamenica and in the 
Secondary School Students' Dormitory "Brankovo kolo" in Novi Sad.

The criteria for including adolescents in the study were the following: the age of the participants aged 12 to 18 ; whether or not a certain form of abuse during adulthood has been sustained (this was determined on the basis of a completed application by a psychologist based on the available data and documentation of the Center for Social Work); the ability to adequately understand the content of items on research instruments (i.e. questionnaires), which was concluded based on a estimate of the verbal functioning of the participants on the Wechsler Abbreviated Scale of Intelligence). Adolescents with a minimum below-average IQ score were included in the study. The criteria for exclusion of adolescents from the examination were: incomplete questionnaire battery. The participants who met the criteria for inclusion in the study signed the participation inform consent. The test was carried out anonymously and with the constant presence of the examiner in order to provide explanations in case of a misunderstanding of the content of the questionnaire. Participants completed questionnaires on their own and independently.

During the research, five questionnaires have been used: the General questionnaire - made especially for the purpose of this research, through which the data on the socio-demographic characteristics of the participants were ad- dressed in the semi-structured manner - with a special focus on the data on psychiatric treatment and physical illness. The questionnaire was filled out by all the participants from the sample, and it took about five minutes to complete the questionnaire; the Wechsler Abbreviated Scale of Intelligence (WASI), Wechsler, (1999) - The WASI test includes three IQ score systems (verbal, manipulative, and total), of which only verbal was used in the research (measurements over two subtests - vocabulary and similarities), for the purpose of a quick estimate verbal functioning of the respondents, i.e. ability of adequate understanding contents of items on other research instruments. It was needed 15 minutes for shooting and solving; the Trauma Symptom Checklist For Children-Alternative (TSCC-A) - intended for self-assessment of posttraumatic pain and associated symptomatology, which contains 44 items that comprise two scales of validity (reduction and exaggeration) and five subcscales (anxiety, depression, anger, posttraumatic stress, dissociation); the Childhood Trauma Questionnaire (CTQ) - an instrument for the retrospective determination of the presence and intensity of emotional, physical and sexual abuse, as well as emotional and physical neglect in the period up to the age of 18 . For each of the mentioned scales, an aadditional classification was also offered - a classification in the form of absent/minimal, 
low, moderate and high intensity choice. The lower limit of the low intensity interval was taken as the limit value for considering the type of abuse or neglect as a dichotomous variable (present/absent). The third questionnaire used in this research was the Adolescent Temperament and Character Inventory questionnaire, ATCI-46 - which contains 46 items with a five-fold scale, based on which the four dimensions of participant's temperament are evaluated (search for novelties, avoidance of danger/punishment, dependence on rewards, persistence) alongside the three dimensions of participant's character (self-directedness, co-operation, self-transcendence).

The data were statistically analyzed by Student's T-test. The results are shown both in a form of a table and a form of a graph. The approval of the competent Ethics Committees (Faculty of Medicine University of Novi Sad, Children's Village "Dr Milorad Pavlovic", Secondary School Students' Dormitory "Branko- vo kolo") for the implementation of the study was also obtained.

\section{RESULTS}

The graph gives an overview of the representation of various forms of abuse among all respondents in group A (Figure 1). In the subgroup of adolescents and multiple forms of abuse, $50 \%$ physical abuse and neglect, $25 \%$ physical and emotional abuse, $8.33 \%$ emotional abuse and neglect, $8.33 \%$ physical and emotional abuse, exploitation and testimony of family violence and $8.33 \%$ physical abuse, neglect and testimony of the family violence. The most common form of violence against male participants is neglect ( $50 \%$ of respondents), and over $50 \%$ of female participants have undergone multiple types of abuse, most commonly intertwined physical abuse and neglect (40\%). According to the data from the application, the participants in the group $\mathrm{C}$ did not suffer any form of violence.

Figure 1 / Grafikon 1 Representation of various forms of abuse in group A / Zastupljenost različitih oblika zloupotrebe u grupi A

Neglect / Zanemarivanje

Multiple abuse / Višestruka zloupotreba

Physical abuse / Fizičko zlostavljanje

Emotional abuse/Emocionalno zlostavljanje

Sexual abuse / Seksualno zlostavljanje 
Among the group-A participants, $20 \%$ of adolescents report that they were advised to visit a psychiatrist (50\% for alcohol abuse or psychoactive substances, $33.33 \%$ for behavioral problems and $16.67 \%$ for emotional problems), and $26.67 \%$ had some type of physical problems ( $50 \%$ heart failure, $25 \%$ vision problems, $12.5 \%$ gynecological problems and $12.5 \%$ several interconnected disorders). In the group C, $6.67 \%$ of adolescents visited their psychiatrists for emotional problems, while $10 \%$ had physical problems $(66.67 \%$ of respiratory problems and $33.33 \%$ of heart disorders).

A statistically significant difference ( $\mathrm{p}$ $<0.05$ ) was observed on the basis of analysis of the symptoms of trauma symptoms in children and adolescents (TSCC-A) in the degree of manifestation of symptoms of anxiety, depression, anger and posttraumatic stress between the $\mathrm{A}$ and C group (Figure 2), and no difference has been noted in the degree of manifestation of the symptoms of dissociation. There is no difference in the severity of posttraumatic suffering among the sexes ( $\mathrm{p}>0.05$ ).

Based on the analysis of the questionnaire on childhood traumatic experiences that were filled by adolescents themselves, it has been noticed that statistically significantly more adolescents from the group A suffered physical and emotional neglect $(\mathrm{p}<0.001)$ and physi$\mathrm{cal}$ and emotional abuse $(\mathrm{p}<0.05)$ in relation to the group $\mathrm{C}$. It was furthermore noticed that adolescents of the group C were significantly more inclined to deny the negative experience in childhood than group A $(\mathrm{p}<0.001)$ (Figure 3$)$. In a group of adolescents with experience of

\section{Figure 2 / Grafikon 2}

Traumatic symptoms for both groups; ${ }^{\star} \mathrm{p}<0.05$

/ Simptomi traume za obe grupe; ${ }^{*} \mathrm{p}<0.05$

"C" group / grupa

[ "A" group / grupa

Posttraumatic stress / Posttraumatski stres

Dissociation / Disocijacija

Anger / Ljutnja

Depression / Depresija

Anxiety / Anskioznost

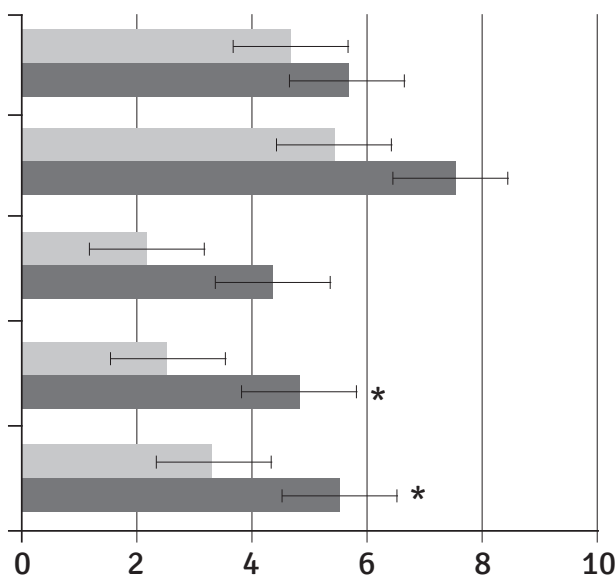


abuse of, five adolescents declared that they experienced some form of sexual abuse, and the important factor that was taken into consideration was that this form of abuse was not registered in a formal application or was not registered by institutions. In the control group, no adolescent pleaded for having been sexually abused.

Based on the analysis of the questionnaire on temperament and character for adolescents, it was noticed that statistically significantly more adolescents from the group $\mathrm{C}$ by character are self-directed $(p<0.001)$ and cooperative $(\mathrm{p}<0.05)$, and are more persistent in temperament $(\mathrm{p}<0.001)$ compared to the A group. Differences in self-transcendence, search for novelties (impul- sivity and excitement) as well as s dependence on rewards and avoidance of danger/error (Figure 4) have not been noticed or determined.

\section{DISCUSSION}

The largest number of adolescents in this study was exposed to neglect and multiple abuse, which is in line with foreign research data, where it has been observed that an increasing number of scientific research data indicate that some types of child abuse do not appear in isolation ${ }^{[21,22,23]}$. The results of this study indicate that neglect and physical abuse are the most commonly associated, which was observed by the scientists in one foreign study, while in the second

\section{Figure 3 / Grafikon 3}

Childhood traumatic experiences for both groups; Note: the value of 5 on abscissa indicates a lack of experience; ${ }^{\star} \mathrm{p}<0.05 ;{ }^{* *} \mathrm{p}<0.001$

/ Traumatsko iskustvo u detinjstvu za obe grupe; napomena: vrednost 5 na apscisi ukazuje na nepostojanje iskustva; ${ }^{\star} \mathrm{p}<0.05 ;{ }^{* \star} \mathrm{p}<0.001$

\section{Minimisation / Minimizacija \\ Physical neglect \\ / Fizičko zanemarivanje \\ Emotional neglect \\ / Emocionalno zanemarivanje \\ Sexual abuse / Seksualno zlostavljanje \\ Physical abuse / Fizičko zlostavljanje \\ Emotional abuse / Emocionalno zlostavljanje}



N 
Figure 4 / Grafikon 4

Questionnaires on temperament and character for both groups; "C" group / grupa

${ }^{\star} \mathrm{p}<0.05 ;{ }^{* *} \mathrm{p}<0.01$

"A" group / grupa

/ Upitnik o temperamentu i karakteru za obe grupe;

${ }^{*} \mathrm{p}<0.05 ;{ }^{* *} \mathrm{p}<0.01$



study from our region there is a highly represented association of neglect and emotional abuse $\mathrm{e}^{[2,22]}$. We note that there are no reports of sexual abuse, which can be explained by the fact that it is more difficult to discover, because the physical, visible consequences of abuse are often missing. Children and adolescents often become confident and reveal abuse years after suffering violence, reflecting the lack of ability of such children to establish trust and intimacy, which is considered the primary consequence of sexual abuse ${ }^{[24]}$. Difficulties in detecting sexual and other forms of abuse are con- firmed by other authors from our area who notice that in some cases of proven family abuse children do not show the consequences; they show optimism and strong cognitive abilities despite the unfavorable circumstances in which they develop. They point out that in such rare cases we must be aware that persons who were victims of sexual abuse at an early age can show symptoms only when they become sexually active themselves ${ }^{[4]}$. The observation in this study is that although there are no reports of sexual abuse, five children from a group of adolescents with an abuse experience, 
through the appropriate questionnaire, have declared that they have suffered some form of sexual abuse in childhood. This fact could confirm all the above assumptions.

According to the findings from the literature, the consequences of abuse and neglect are numerous. This study shows the late effects of child abuse in the adolescent age. A higher percentage of abused and/or neglected adolescents in relation to non-abused and non-neglected participants ask for help in order to deal with mental disorders, mostly disorders related to behavioral problems, substance abuse and somatoform problems. Also, these adolescents have more extreme difficulties in the form of delinquent and aggressive behavior. These observations are in line with the research of other authors, which further state that two forms of mother behavior (neglect and testimony to family violence) and one form of father behavior (emotional abuse) provide the best prediction of the overall problems in the functioning of the child ${ }^{[2,4,25]}$. In the adolescent age, symptoms of trauma in abused children are still present ${ }^{[26]}$. Children tend to accuse themselves of incomplete cognitive development, dependence on adults, and an awareness of adults in meeting their needs. They are more vulnerable than adults and violence threatens their current psychophysical health, as well as further psychophysical and social development ${ }^{[9]}$. It is possible that children who have been physically abused adopt aggressive patterns of behavior and later become abusers themselves ${ }^{[4]}$. The connection between physical punishment and aggressive and antisocial behavior in children in foreign studies has also been proven ${ }^{[27,28]}$. The literature also states that post-traumatic stress disorder can occur in abused children within the family, that such children have a lower intelligence coefficient, and that it is possible to manifest attention deficit and attachment disorders, hyperkinetic disorder and have lower academic achievements in relation to non-abused children ${ }^{[26]}$.

Impaired quality of life of violence victims is reflected in the form of low self-esteem, various physical and emotional difficulties, poor achievements in school, as well as the achievement of unstable friendly and emotional relationships ${ }^{[29]}$. Our research has shown similar results. Adolescents with experience of abuse have shown that they have difficulties in the development of individual characteristics of character and temperament, such as co-operativeness, self-direction and persistence, i.e. the difficulty of setting goals for themselves, to achieve an independent identity, not being self-confident enough, to accept and identify with other people, to be persistent and tolerant of the frustration of dealing with difficult and tedious demands. They are known not to be persistent in the jobs they start and work less 
well with others. As character dimensions develop predominantly under the influence of environmental factors and interaction with the environment, adverse life experiences such as abuse are expected to be significant for character development, and possibly children and adolescents with aversive experiences will have more negative character traits, which is consistent with our results. The persistence dimension is the only dimension of temperament within the Cloninger model that is not related to a particular neurotransmitter system, so it has no clear genetic basis, and may be more susceptible to environmental influences, which is consistent with the results of our study that abused children have lower levels of persistence. According to Cloninger, in that way they are at the risk of developing problems in the adult age in the form of personality disorders, substance abuse and dissociative symptoms ${ }^{[30]}$. The results of our study are consistent with other studies that demonstrated that experience of abusive treatment leave an impact on victims personality development, specifically on their emotional and social adjustment, self-esteem and well-being.

The fact is that each abusive experience is unique and that every child requires individual examination and guided support. By increasing the number of research in this field, the attention of the professional public is drawn to this ever-present phenomenon in our region ${ }^{[4]}$. The need for professional access to these children at an early age is emphasized, since early recognition of violence against children allows the inclusion of appropriate social support and treatment measures, including the removal of a child from a violent environment. The aim of these procedures is to enable normal neuroanatomical and biological development of a child [26]. Awareness of serious long-term consequences of child abuse should encourage better identification of those at risk and develop effective interventions to protect children from violence ${ }^{[31]}$. In research led by foreign authors, the importance of increasing the resistance of children exposed to abusive environments, mastering the skills of solving problems, improving safe school environment and settlements is increasingly emphasized in order to reduce the risk of unintended consequences in children who are traumatized. Periodic evaluations of the quality of life among school students are suggested in order to identify the symptoms as soon as possible and to provide the necessary assistance in the form of psychological and psychiatric and other types of medical support ${ }^{[29]}$. It is necessary to carefully select instruments and patterns for examining childhood violence and be consistent in measuring and defining abuse, taking into account that registered and officially registered cases are only "the tip of the iceberg" $[2,26,31,32]$.

The limitations of this research are 
reflected in the way in which psychosocial and personality traits are interpreted, which probably did not arise solely as a result of abuse, but as a result of a whole variety of other factors, above all, growing up in the dormitory, outside the family, but also the fact that such children carry certain genetic, biological factors and early adversive socio-economic conditions. In this study, we also did not differentiate between different forms of abuse and we did not independently observed characteristics of children with specific forms of abuse. In addition, this is a selected sample and is not representative of the entire population of abused and/or neglected children. Also, there is a small number of available papers that are examining children from this type of social protection and with which we can compare our results, because in the countries of the European Union a minimal number of children are placed in collective accommodation.

\section{CONCLUSION}

This research has confirmed the existing opinion of many domestic and foreign authors that the cumulative effect of childhood abuse and neglect can lead to the manifestation of very complex symptoms in adolescents. The results have shown the multiple and long-term difficulties and symptoms of childhood maltreatment that manifest themselves in the adolescent age, which points to the specific needs of abused and neglected adolescents for psycho-psychiatric support and treatment, in order to prevent and soften later consequences in adulthood. Such children require a specific type of support throughout the whole developmental period. 


\section{TRAUMATSKI SIMPTOMI I CRTE LIČNOSTI KOD ADOLESCENATA SA ISKUSTVOM ZLOUPOTREBE U DETINJSTVU}

\section{Ana-Marija Vejnovićc ${ }^{1,2}$ Svetlana Ivanović Kovačevićc ${ }^{1,2}$ Valentina Šobot ${ }^{1,2}$}

1 Klinički centar Vojvodine, Klinika za psihijatriju, Novi Sad, Srbija

2 Univerzitet u Novom Sadu, Medicinski fakultet,

Katedra za psihijatriju i psihološku medicinu,

Novi Sad, Srbija

UDK: 616.89-008.44-052.3-02 doi: $10.5937 /$ engrami $1902034 \mathrm{~V}$

\section{Kratak sadržaj}

Uvod. Zlostavljanje i zanemarivanje dece je opšti problem koji prožima ceo svet. Ono može da ugrozi fizički, psihički i socijalni integritet deteta i ostavi posledice u kasnijem životnom dobu. Cilj studije je bio da ispitamo traumatske simptome i obeležja ličnosti kod adolescenata sa iskustvom zloupotrebe u detinjstvu.

Materijal i metode. Obuhvaćeno je 60 ispitanika oba pola, starosti 12 do 18 godina, podeljenih u dve grupe ujednačene po polnoj i uzrasnoj strukturi (grupa zlostavljane dece i adolescenata "A" i kontrolna grupa „C”). Koristili smo pet upitnika: Opšti upitnik, Vekslerovu skraćenu skalu inteligencije, Skala simptoma traume kod dece, Upitnik o traumatskim iskustvima u detinjstvu i Upitnik o temperamentu i karakteru za adolescente. Statistički su podaci obrađeni Studentovim T-testom. 
Rezultati. U grupi zlostavljane dece, $46,67 \%$ dece je zanemarivano, $10 \%$ dece je fizički zlostavljano, 3,33\% emocionalno zlostavljano, dok je njih $40 \%$ pretrpelo više oblika zlostavljanja. U „C” grupi su po karakteru značajnije samousmereni $(\mathrm{p}<0,001)$ i kooperativni $(\mathrm{p}<0,05)$, a po temperamentu istrajniji $(\mathrm{p}<0,001) \mathrm{u}$ odnosu na „A” grupu. Anksioznost, depresivnost, ljutnja i posttraumatski stres su izraženiji u "A” grupi.

Zaključak. Višestruke i dugotrajne emocionalne teškoće kod adolescenata sa iskustvom zlostavljanja u detinjstvu nam ukazuju na specifične potrebe zlostavljanih adolescenata za psihološko-psihijatrijskom podrškom i tretmanom, u cilju prevencije i ublažavanja kasnijih posledica u odraslom dobu.

\section{Ključne reči:}

zlostavljanje, zanemarivanje, karakter, temperament, posledice

\section{LITERATURE / LITERATURA}

1. Pejović-Milovančević M, Minčić T, Kalanj D. Priručnik za primenu Posebnog protokola sistema zdravstvene zaštite dece od zlostavljanja i zanemarivanja. Beograd: Institut za mentalno zdravlje; 2012.

2. Isaković 0 . Percipirano zlostavljanje i zanemarivanje u porodičnim relacijama i funkcionalnost adolescenata. U: Zotović M, Mihić I, Jerković I, Marinković L, Damjanović D, Šilić V. et al. Porodice u Vojvodini: karakteristike porodica u posebnim uslovima. Novi Sad: Filozofski fakultet Novi Sad, 2011: 98-114.

3. vanović-Privrodski J. Pedijatrija za studente medicine Novi Sad: Medicinski fakultet Novi Sad, 2012; 941-8.

4. Pejović-Milovančević M. Zaštita dece žrtava i svedoka krivičnih dela psihološki aspekt. Beograd: Ministarstvo pravde. 2014:71.

5. Kostić M. Protiv detetove volje: dete, porodica i seksualno zlostavljanje. U: Popović D. Meunardoni simpozijum: „Seksualnost, agresivnost, delinkventnost: medicinski, pravni i socijalni aspekti seksualne delinkvencije. Novi Sad: Matica srpska, 1999; 141-53.

6. Stjuart In, Doins V. Savremena transakciona analiza. Novi Sad: Psihopolis institut. 2011.

7. Lensdaun G. Childrens Rights u Berry Mayall: Childrens Child hoods: Observed Experienced. London: The Falmer Press. 1994;199:45-63.

8. Developingchild.harvard.edu [internet 
stranica]. InBrief: The Science of Eraly Childhood Development [citirano u avgustu 2016]. Dostupno na: http://developingchild.harvard.edu/ resources/inbrief-science-of-ecd/

9. Popov I. Psihološke i psihopatološke karakteristike žrtava nasilja.U:

Popović D. Meunarodni simpozijum: „Seksualnost, agresivnost, delinkventnost: medicinski, pravni i socijalni aspekti delinkvencije". Novi Sad: Matica srpska, 1999; 195-8.

10. Smearman E et al. Oxytocin Receptor Genetic and Epigenetic Variations: Association With Child Abuse and Adut Psychiatric Symptoms. Child development. 2016;87(1):122-34.

11. Pejović-Milovančević $M$, IšpanovićRadojković V, Vidojević 0 , Minčić T, Radosavljev J. Psihološke posledice zlostavljanja i zanemarivanja dece i adolescenata. Psihijatrija danas. 2001; 33(3-4): 175-87.

12. Evren C, Evren B. Self-mutilation in substance-dependent patients and relationship with childhood abuse and neglect, alexithymia and temperament and character dimensions of personality. Drug and Alcohol Dependence. 2005; 80: 15-22.

13. Marini R, Hasniza I, Syirin M, Rahmi R, Nuraya. The personality development of child abuse survivors. Journal of Humanities, Language, Culture and Business (HLCB). 2017; 1(2): 1-9.

14. Enache, R. Psychological counseling and developing resilience for young people with psychological trauma in childhood or adolescence. Journal of Experiential Psychotherapy. 2016; 19 (1): 73.

15. Cloninger CR, Svrakic DM, Przybeck TR. A psychobiological model of temperament and character. Arch Gen Psychiatry. 1993; 44: 573-88.

16. Džamonja-Ignjatović T, Knežević G. Psihobiološki model temperamenta i karaktera -validacija i kroskulturalna komparacija. Psihologija. 2005; 38(3): 295-309.

17. Zohar AH. The Blatt and the Cloninger models of personality and their relationship with psychopathology. Isr J Psychiatry Relat Sci. 2007; 44 (4): 292-300.

18. Mariani M, Asnarulkhadi AS. A descriptive analysis on the personality of child physical abuse victims. International Journal of Business and Social Science. 2009; 2 (14): 228-40.

19. Dalbudak E, Evren C, Çetin T, Durkaya M, Cetin R. History of trauma and relationship with alexithymia, temperament and character dimensions in male alcohol dependent inpatients. Düünen Adam. 2010; 23(1): 1-12.

20. Joyce PR, McKenzie JM, Luty SE, Mulder RT, Carter JD, Sullivan PF et al. Temperament, childhood environment and psychopathology as risk factors for avoidant and borderline personality disorders. Aust N Z J Psychiatry. 2003; 37(6): 756-64.

21. Higgins DJ, McCabe MP. Multi-type maltreatment and the long-term adjustment of adults. Child abuse review. 2000; 9(1): 6-18.

22. Araghol F. et al. Identification and Evaluation of Abused Children at Imam Hossein Hospital. Int J High Risk Behav Addict. 2016;5(1):e27531.

23. Iniguez KC, Stankowski RV. Adverse Child Experiences and Health in Adulthood in a Rural Population-Based Sample. CM\&R Rapid Release. 2016: 
10.3121.

24. Mullen PE, Fleming J. Long-term Effects of Child Sexual Abuse.

Melbourne: Australian Institute of Family Studies; 1998.

25. Arias I. The Legacy of Child Maltreatment: Long-Term Health Consequences for Women. Journal of women's health. 2004; 13(5): 468-73.

26. Tsavoussis A, Stawicki SPA, Stoicea N, Papadimos TJ. Child-Witnessed Domestic Violence and its Adverse Effects on Brain Development: A Call for Societal Self-Examination and Awareness. Front. Public Health. 2014; 2:178.

27. Gershoff ET. Corporal punishment by parents and associated child behaviors and experiences: A meta-analytic and theoretical review. Psychological bulletin. 2002; 128(4): 539-79.

28. Grogan-Kaylor A. The effect of corporal punishment on antisocial behavior in children. Social work research. 2004; 28(3): 153-64.

29. Greger HK, Myhre AK, Lydersen S, Jozefiak T. Child maltreatment and quality of life: a study of adolescents in residental care. Health and Quality of Life Outcomes. 2016;14:74.

30. Šobot V, Ivanović Kovačević S, Marković J, Mišić Pavkov G, Novović Z. Role of sexual abuse in development of conversion disorder: case report. European Review for Medical and Pharmacological Sciences. 2012; 16:276-9.

31. Norman RE, Byambaa M, De R, Butchart A, Scott J, Vos T. The LongTerm Health Consequences of Child Physical Abuse, Emotional Abuse, and Neglect: Systematic Review and Meta-Analysis. PLOS Medicine. 2012;
9: 1-31.

32. Ivanović Kovačević S, Mišić Pavkov G, Gajić Z, Šobot V. Zlostavljanje dece i posledice po razvoj dece - prikaz slučaja. Aktuelnosti iz neurologije, psihijatrije i graničnih područja. 2005; 13(3-4): 65-8.

\section{Dr Ana-Marija Vejnović}

Klinika za psihijatriju, Klinički centar Vojvodine Hajduk Veljkova 1-7, 21000 Novi Sad, Srbija ana-marija.vejnovic@mf.uns.ac.rs 